\title{
DEVELOPMENT AND EVALUATION OF THERMAL AND CHEMICAL MICROALGAE CELL DISRUPTION METHODS FOR BIOFUELS AND BIOPRODUCTS PRODUCTION
}

\section{DESARROLLO Y EVALUACION DE METODOS DE DISRUPCION CELULAR TERMICA Y QUIMICA PARA LA OBTENCION DE BIOCOMBUSTIBLES Y BIOPRODUCTOS}

\footnotetext{
${ }^{1}$. Doctor in Chemical Engineering, University of Cartagena, Avenida del Consulado \# Calle 30 No. 48 - 152 , Cartagena de Indias, Colombia, E-mail: agonzalezd1@unicartagena.edu.co

2. Master in Chemical Engineering, Universidad Nacional Abierta y a Distancia UNAD, E-mail: yeimmy.peralta@ unad.edu.co

${ }^{3 .}$ Doctor Ingener habil, Center for sustainable Development in Industry and Energy, Industrial University of Santander, Cra 27 Cll 9 Ciudad Universitaria, Bucaramanga, Colombia, E-mail: cisyc@uis.edu.co

Recibido: 03 Diciembre de 2015 Aceptado: 22 Diciembre de 2015

*Correspondencia del autor: E-mail: agonzalezd1@unicartagena.edu.co
}

\begin{abstract}
RESUMEN
La biomasa de microalgas continúa siendo objeto de estudio como candidata promisoria para la obtención de biocombustibles y bioproductos, sin embargo, los procesos de aprovechamiento de microalgas enfrentan cuellos de botella técnicos relacionados con la eficiencia de extracción y transformación de metabolitos. Este articulo muestra el desarrollo y la evaluación de métodos térmicos y quimicos para la extracción de aceite de Nannochloropsis sp. como materia prima para la producción de biocombustibles de tercera generación y acidos grasos de alto valor agregado. El proceso de disrupción celular térmica elegido fue autoclave, durante tiempos de operación de 1 y 3 horas a $394.15 \mathrm{~K}$ y $103410 \mathrm{~Pa}$. El tratamiento químico se basa en la hidrólisis ácida con $\mathrm{HCl}$ en concentraciones de $0.1,0.5,1$ y $3 \mathrm{~mol} \mathrm{~L}^{-1}$. Además, se utilizó el pretratamiento Organosolv con un tiempo de reacción de 4.1 horas a $394.15 \mathrm{~K}$ y $103410 \mathrm{~Pa}$. Los resultados mostraron que el proceso de disrupción celular térmica y Organosolv aumenta los rendimientos de extracción de la biomasa sin pretratamiento, pero éstos no exceden cualquiera de los resultados obtenidos mediante hidrólisis ácida. La solución de $\mathrm{HCl} 0.5 \mathrm{~mol} \mathrm{~L}^{-1}$ demostró ser la más adecuada para el proceso de ruptura celular. Además se determinó que el contenido de agua en la biomasa pretratada, disminuye la eficiencia en los procesos de extracción.
\end{abstract}

Palabras claves: Microalgas, disrupción celular, extracción, extracto lipídico. 


\begin{abstract}
Biomass of microalgae continues under study as promising candidate for novel biofuels and bioproducts, however, microalgae-based processes faces technical bottlenecks related to efficiency of metabolite extraction and transformation. This paper shows the development and evaluation of thermal and chemical cell disruption methods for the extraction of oil from Nannochloropsis sp. as feedstock for the production of third generation biofuels and high value fatty acids, in order to achieve lipid extraction efficiency. The thermal cell disruption process chosen was autoclave, during operation times of 1 and 3 hours at $394.15 \mathrm{~K}$ and $103410 \mathrm{~Pa}$. Chemical treatment was based on acid hydrolysis with $\mathrm{HCl}$ in concentrations of $0.1,0.5,1$ and $3 \mathrm{~mol} \mathrm{~L}^{-1}$. Organosolv Pretreatment was also used with a reaction time of 4.1 hours at $394.15 \mathrm{~K}$ and 103410 $\mathrm{Pa}$. Results showed that the thermal and Organosolv cell disruption process increases extraction yields for biomass without pretreatment, but these did not exceed any of the results obtained with acid hydrolysis. Solution $0.5 \mathrm{~mol} \mathrm{~L} \mathrm{~L}^{-1} \mathrm{HCl}$ proved to be the most suitable for cell disruption process. In addition it was determined that the water content in the pretreated biomass, decreases the efficiency of the extraction processes.
\end{abstract}

Keywords: Microalgae, cell disruption, extraction, lipid extracts.

\section{INTRODUCTION}

The increasing oil prices and environmental problems arising from the use of fossil fuels, urgently demanding alternative sources of energy to be a promising option for biofuels. They offer many benefits related to energy security, economic stability and reducing the environmental impact caused by greenhouse gases (1).

The first-generation biofuels derived from crops such as sugarcane land, sugar beets, corn, soy etc., leads to a tremendous strain on global food markets. The second generation produced from biomass feedstock, faces the above problems, but there is great concern about competition in land use and changes to it. Therefore, based on current scientific knowledge and technology projections, third-generation biofuels, specifically derived from microorganisms, are considered as a viable energy resource that has no major problems associated with the first and second generation biofuels (2).

The use of microalgae for biodiesel production is an advantageous alternative because of the high lipid content and fatty acid profile that suitable offers. In addition, other attributes of microalgae are its high photosynthetic efficiency, its ability to grow in marine waters, sweet, and brackish waste and its relatively high growth rate (3). However, the production of biodiesel from microalgae has certain limitations related to the paucity of information for scaling up, high operating costs and standardization of methods for efficient extraction (4).

Against this background and in the framework of the "Bioprospecting Colombian microalgae for biodiesel production", authors proposed the development of a laboratory-scale method for extracting lipids from microalgae, making a comparative study of the processes of thermal and chemical cell disruption.

\section{MATERIALS AND METHODS}

\subsection{Raw material}

The biomass was provided by the Institute Morrosquillo (Punta Bolivar, Colombia) under the codes IM20091203 and IM20091228-01-11 for the genera Nannochloropsis sp., and a mixture of Navicula sp. / Scenedesmus sp. grown in open ponds in enriched medium sea water, harvested by flocculation (150 ppm $\mathrm{FeCl}_{3}$ ) and sun dried.

\subsection{Preliminary tests}

Preliminary tests were performed using a mixture of the genera Navicula sp. and Scenedesmus sp., in order to establish qualitatively the effect caused by chemical agents on cells. $5 \mathrm{~g}$ of sample were deposited into 4 glass containers. Each container was added $100 \mathrm{~mL}$ of $0.5 \mathrm{~mol} \mathrm{~L}-1 \mathrm{NaOH}, 0.5 \mathrm{~mol} \mathrm{~L}^{-1} \mathrm{HCl}$, analytical grade chloroform and hexane and were subjected to autoclave for 1 hour at $394.15 \mathrm{~K}$ and $103410 \mathrm{~Pa}$. Aliquots were taken from each container and were observed under light microscopy at 100X. In addition, samples were taken of the mixture, which was not subjected to 
any treatment (control). Parallel tests were performed lipid extraction with wet and dry biomass, to establish the effect of moisture content in the extraction yield. The methodology used corresponds to Figure 2.

\subsection{Pretreatment of biomass}

\subsubsection{Cell Disruption}

Figure 1 summarizes the processes for cell disruption performed on the microalgae of the genera Nannochloropsis sp. Biomass was previously crushed and dried at $378.15 \mathrm{~K}$ for 4 hours. Subsequently, it was exposed to three cell disruption processes separately: Thermal, chemical and Organosolv (methanol / acid). Two replicates were conducted for each experiment.

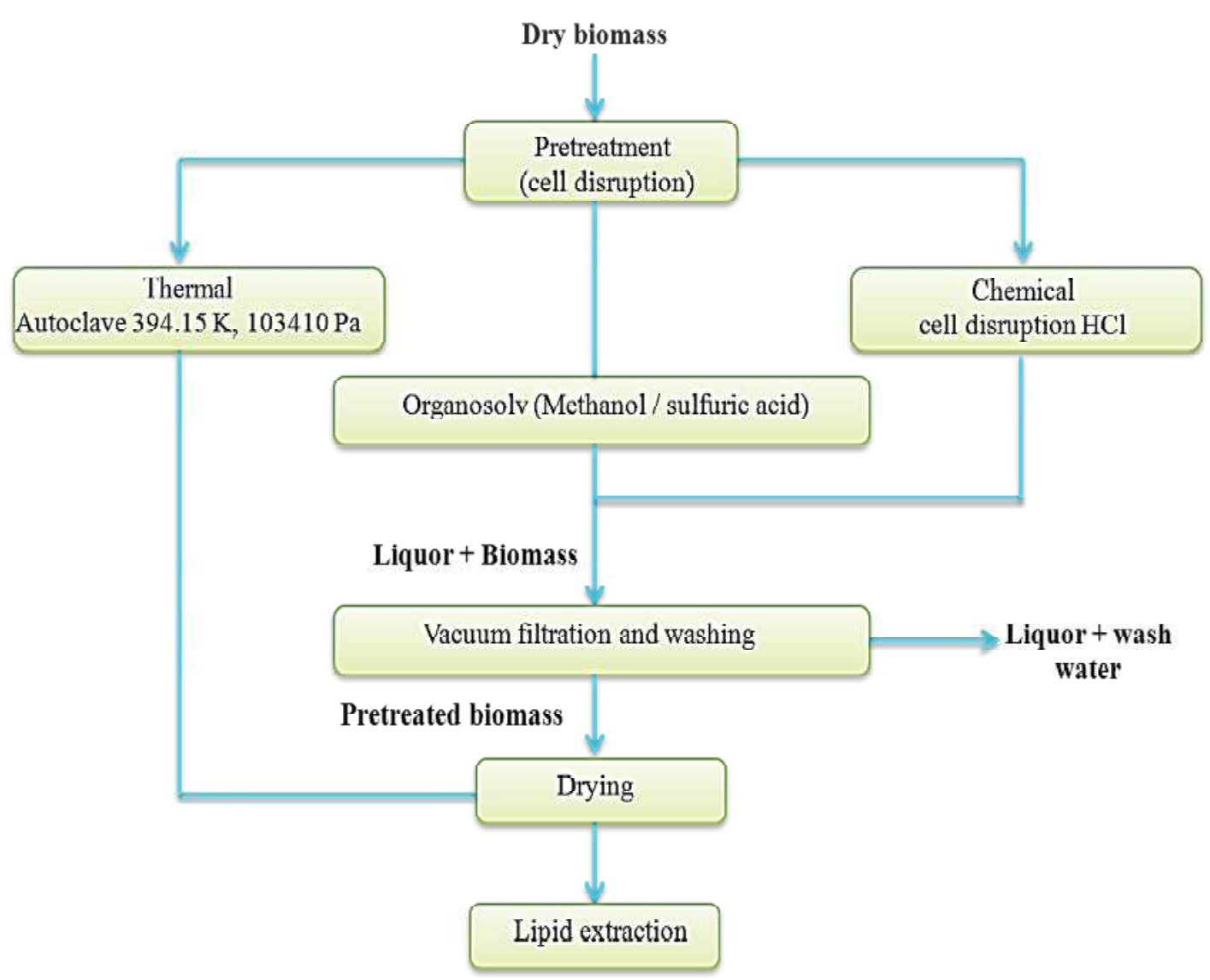

Figure 1. Processes for cell disruption.

\subsubsection{Thermal cell disruption}

$3 \mathrm{~g}$ of biomass were underwent to a process of cell disruption thermal in electric sterilizer autoclave to $394.15 \mathrm{~K}$ and $103410 \mathrm{~Pa}$ during a time of $1 \mathrm{~h}$ and $3 \mathrm{~h}$.

\subsubsection{Chemical cell disruption}

$3 \mathrm{~g}$ of hydrolyzed biomass with different $\mathrm{HCl}$ solutions at concentrations of $0.1 \mathrm{~mol} \mathrm{~L}^{-1}, 0.5 \mathrm{~mol} \mathrm{~L}^{-1}, 1$ mol L-1 and $3 \mathrm{~mol} \mathrm{~L}^{-1}$ with an exposure time of 0.5 hours with magnetic stirring at room temperature.

\subsubsection{Organsolv Methanol/Acid}

Organosolv Methanol-acid pretreatment proposed for obtaining reducing sugars (5) was applied parallel with the following condiones: $3.32 \% \mathrm{v} / \mathrm{v}$ methanol and $0.6 \mathrm{~mol} \mathrm{~L}^{-1} \mathrm{H}_{2} \mathrm{SO}_{4}$ solution and a reaction time of $4.1 \mathrm{~h}$ at $394.15 \mathrm{~K}$ and $103410 \mathrm{~Pa}$.

\subsection{Filtering, washing and drying of pretreated biomass}

After the pretreatment, the biomass was separated from the liquor by vacuum filtration. Separate biomass was washed with distilled water and dried in oven at $378.15 \mathrm{~K}$ for 4 hours. Subsequently, continued the extraction step.

\subsection{Lipid extraction and quantification}

Lipid extraction was performed according to each pre- 
treatment applied to the biomass of the genera Nannochloropsis sp., with the aim to propose a comparative study between them and determine the most effective. The lipid extraction and purification was based on the methodology proposed by Ramírez Fajardo et al. (2007), using ethanol and hexane as solvents for ex- traction and purification (6). Figure 2 illustrates the method used. The quantification of lipid extract was determined with the aim of evaluating the performance of the process and obtains an indirect measure of the effect caused by pretreatment of cells.

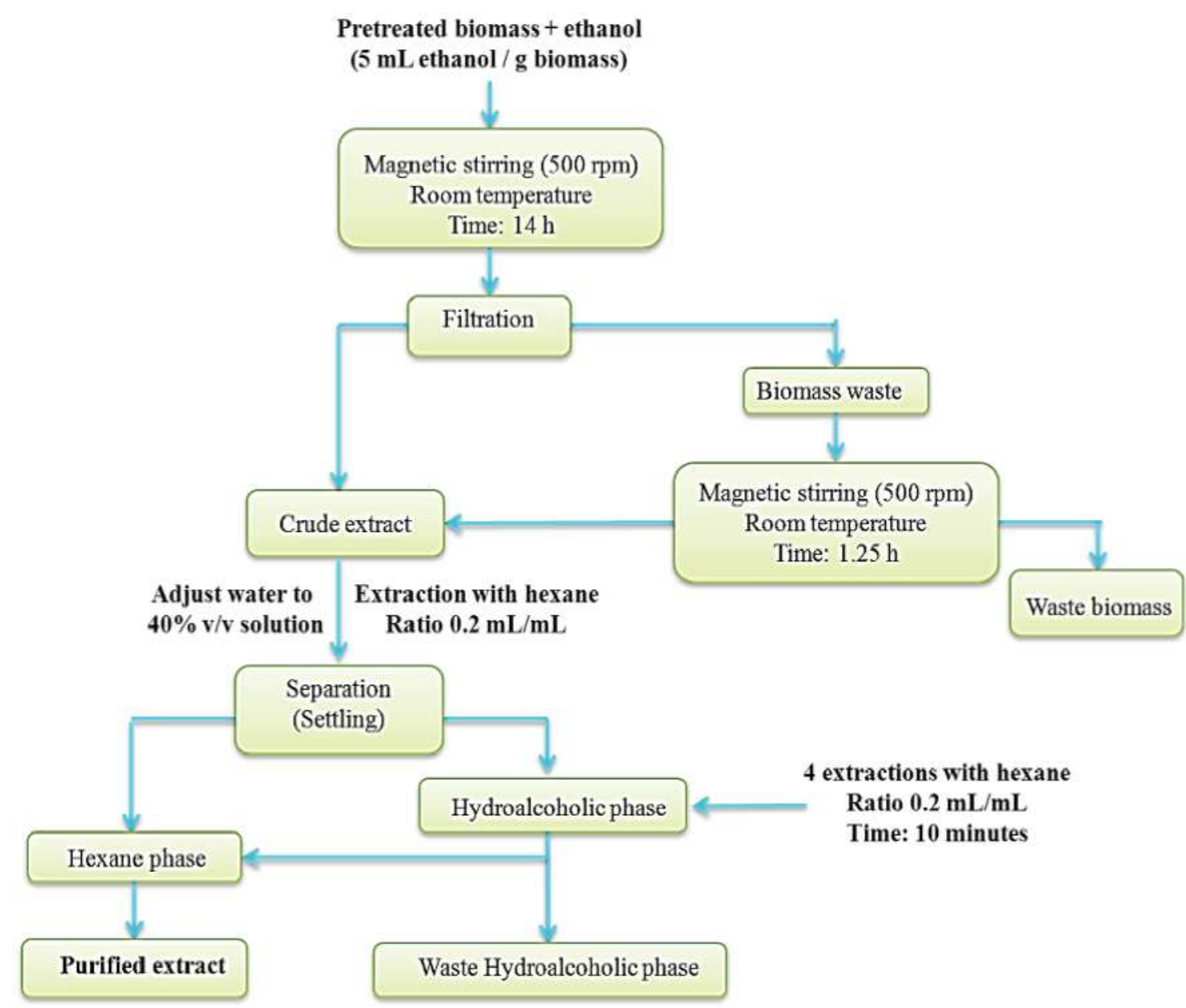

Figure 2. Lipid extraction based on the methodology proposed by Ramírez Fajardo, et al. (2007).

\section{RESULTS AND DISCUSSION}

The chemical composition of the microalga Nannochloropsis sp., reported by the Colombian Petroleum Institute (ICP) is shown in Table 1. Nannochloropsis sp. had a higher proportion of protein, this biomolecule was found at a concentration of $21.2 \% \mathrm{w} / \mathrm{w}$, followed by lipids. The large amount of ashes reported were caused by the effect of flocculant.
Table 1. Chemical composition of the microalga Nannochloropsis sp.

\begin{tabular}{lcccc}
\hline \multirow{2}{*}{$\begin{array}{l}\text { Microalgae } \\
\text { Nannochlo- }\end{array}$} & $\begin{array}{c}\text { Protein / } \\
\mathbf{\%} \mathbf{w} / \mathbf{w}\end{array}$ & $\begin{array}{c}\text { Carbohydrates / } \\
\mathbf{\%} \mathbf{w} / \mathbf{w}\end{array}$ & $\begin{array}{c}\text { Lipids / } \\
\mathbf{\%} \mathbf{w} / \mathbf{w}\end{array}$ & $\begin{array}{c}\text { Ash / } \\
\mathbf{\%} / \mathbf{w}\end{array}$ \\
\cline { 2 - 5 } ropsis sp. & 21.1 & 3.3 & 11.2 & 57.5 \\
\hline
\end{tabular}




\subsection{Preliminary tests}

Figure 4 shows the changes caused by treatment with chloroform, hexane, sodium hydroxide and hydrochloric acid on the cells of Navicula sp. and Scenedesmus sp, which are observed as untreated cells in Figure 3.

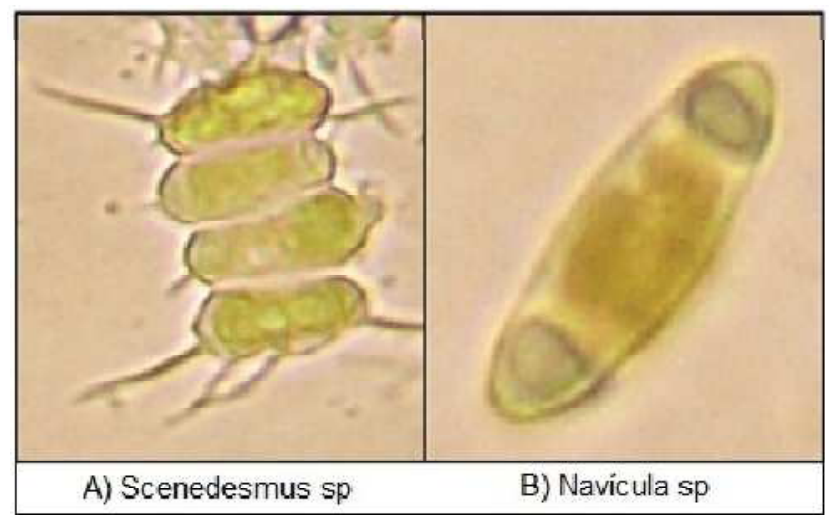

Figure 3. Untreated cells of Navicula sp. and Scenedesmus sp.

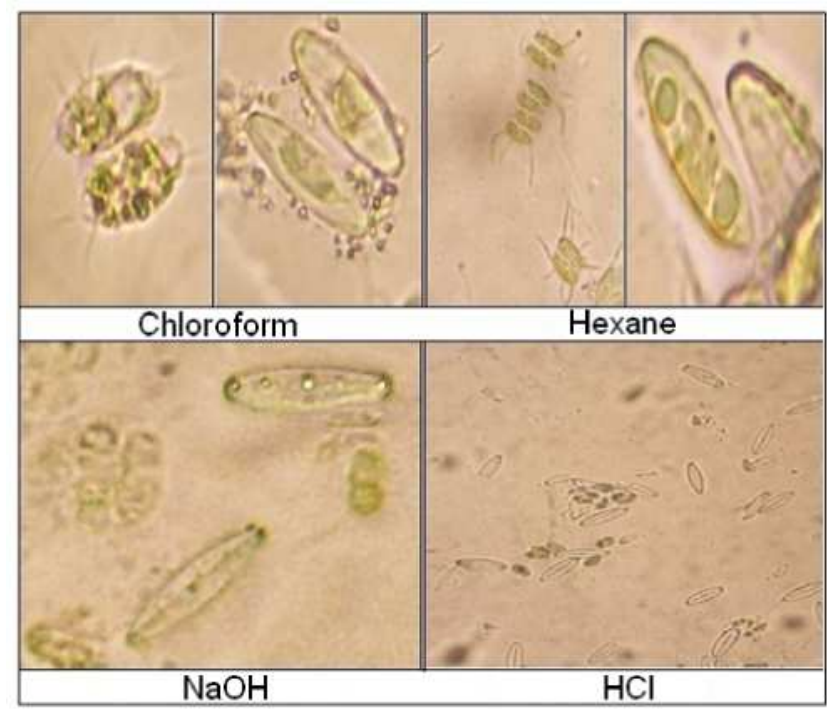

Figure 4. Changes in cells of Navicula sp. and Scenedesmus sp caused by different reagents.

Changes on cells in the treatment with hexane and chloroform were observed as a difference in coloration and deformation of the internal structure. Although chloroform promoted the release of intracellular content in the genera Navicula sp., morphological changes and leaflets were not evident in any of the two treatments. According to this, Dos Santos, et al. (2015), explain that when a microalga cell is exposed to a non-polar organic solvent, such as hexane and chloroform, the solvent penetrates the cell membrane and interacts with neutral lipids (i.e., triglycerides) present in the cytoplasm because of van der Walls forces, to form an organic solvent-neutral lipid complex, which diffuses across the cell membrane and the static organic solvent film surrounding the cell, entering the organic solvent. As a result, the neutral lipids are extracted from the cells and remain dissolved in the non-polar organic solvent (7).

Even though these changes demonstrate the permeation of solvent through the cell wall, do not guarantee release a large proportion of intracellular products desired because the Van der Waals interactions formed between non-polar organic solvents and neutral lipids are inadequate to disrupt the membrane-based lipid-protein associations (these last ones are formed when some neutral lipids found in the cytoplasm as a complex with polar lipids - i.e., phospholipids, glycolipids, sterols, carotenoids-, are strongly linked via hydrogen bonds to proteins in the cell membrane), making it necessary to use a polar organic solvent, such as methanol or ethanol (7).

On the other hand, the treatment with hydrochloric acid affected morphologically some cells, mainly of the genera Navicula sp., causing the breakdown of cellular leaflet. Changes were presented as to the disposition of the dispersed colonies and the coloration, and release the intracellular content of spiny projections gender Scenedesmus sp. In the study reported by Miranda, et al. (2012), where the response variable was the total amount of sugars extracted from Scenedesmus Obliquus, the acid pre-treatment method $(\mathrm{HCl}$ and $\mathrm{H}_{2} \mathrm{SO}_{4}$ ) revealed to be the best for disruption/sugar extraction for both dried and wet biomass (8).The changes in cells are caused by acid hydrolysis related to polysaccharides that make up the cell wall and decomposition of siliceous material, which consist the shells of diatoms.

Finally, the damage caused by sodium hydroxide is between those caused by acid and organic solvents. There were changes in color and morphology of the cells, but did not show drastic effects on the cell walls of microalgae. Günerken, et al. (2015) explain this might occurs because bases saponify the membrane lipids while acids lead to poration of the cell membrane/wall (9).

According to the qualitative results obtained and knowledge of the cell wall is a limiting factor in the lipid extraction, was decided to use hydrochloric acid as an agent for chemical cell disruption processes, since the effects were more evident with the treatment 
and mainly on the genera Navicula sp.

\subsection{Influence of moisture in biomass lipid extrac- tion}

Table 2 shows the yields obtained from the lipid extraction process using wet and dry biomass. These tests were performed with a mixture of Navicula sp. and Scenedesmus sp. The disruption of the cell wall is specific for each species of microalga, as each has a particular cell wall which may confer more or less resistance to mechanical and chemical stress. It is probable that the drying process improves cell disruption by weakening the cell wall, which thereby improves the lipid extraction yield (8).

Table 2. Data on the influence of moisture on the extraction of lipids.

\begin{tabular}{ccccccc}
\hline Pretreatment & *Wet basis/g & Dry basis/g & Average extracts/g & Standard deviation & Y / \% w/w & L/ \% w/w \\
\hline Wet & 10 & 2.26 & 0.0337 & 0.0028 & 1.49 & 30.8 \\
Dry & 0 & 2.26 & 0.0629 & 0.0033 & 2.8 & 9.36 \\
\hline
\end{tabular}

* 77.4\% w/w moisture; Y: dry basis yield biomass; L: losses

Figure 5 compares the yields obtained with wet and dry sample. It is shown that the water content in the sample is not favorable for the extraction of lipids due to two reasons.

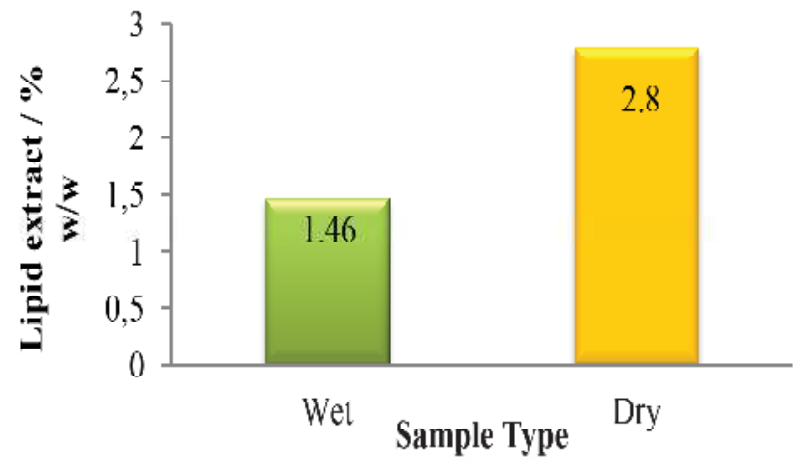

Figure 5. Extraction yields of wet and dry biomass.

First, the presence of water in the sample decreases the concentration of ethanol in the biomass / solvent mixture during the first stage of the process, reducing the efficiency of solvent extraction of crude oil. From the above table, it is shown that $10 \mathrm{~g}$ of wet biomass containing $7.74 \mathrm{~g}$ of water. This causes a decrease of $40 \% \mathrm{w} / \mathrm{w}$ ethanol concentration, which decreases its extractive capacity.

Secondly, reported losses reflect the presence of moisture in the sample handling difficulties, mainly due to the adhesion of biomass to the elements and utensils used during each stage of the process. This is an untoward occurrence, since a fraction of the biomass would not be exploited for the extraction of lipids.

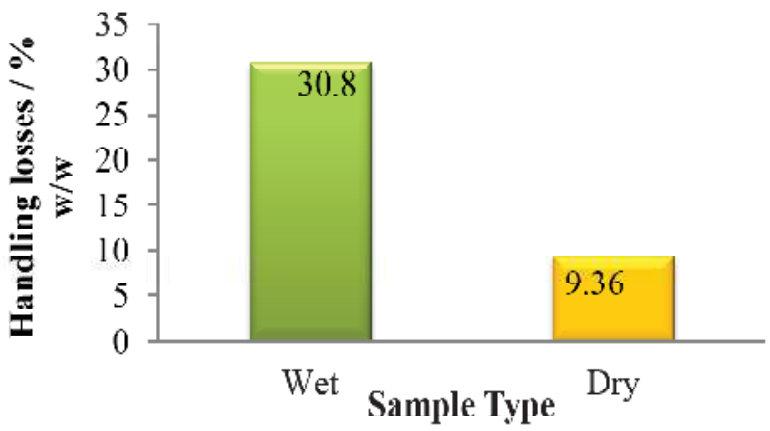

Figure 6. Losses due to handling with wet and dry biomass.

\subsection{Effect of autoclaving time}

The thermal pretreatment results are shown in Table 3. Although this process of cell disruption showed a significant increase in biomass without pretreat the recovery rate of lipids in a time of 3 hours (Figure 7), failed to overcome any of the results obtained with the other pretreatments. This might have occurred because thermal pretreatment damages cell walls but not rupture cells (10). The recovery percentages for autoclave worked times do not differ by more than $1.2 \% \mathrm{w} / \mathrm{w}$ despite increased exposure time to 2 hours.

Table 3. Data obtained from Autoclave Pretreatment.

\begin{tabular}{ccccc}
\hline Pretreatment & Average extracts/g & Standard deviation & LR / \% w/w & Y / \% w/w \\
\hline Autoclave / 1h & 0.0168 & 0.0004 & 4.9 & 9.46 \\
Autoclave / 3h & 0.0206 & 0.0015 & 6.07 & 9.35 \\
Control & 0.0098 & 0.0014 & 2.85 & 9.58 \\
\hline LR: \% w/w lipid recovery in the total biomass; Y: Losses of biomass through handling.
\end{tabular}


This allows us to infer that time worked above the maximum operation, represent a large and unnecessary energy expenditure.

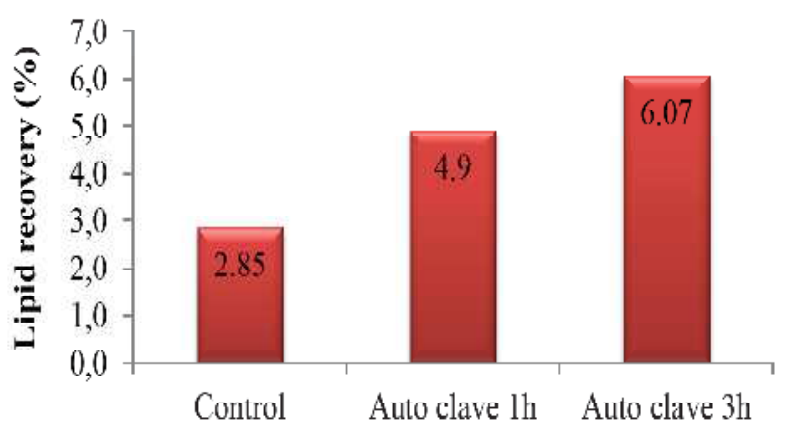

Figure 7. Effect of autoclave time on the recovery rate of lipids.

\subsection{Effect of $\mathrm{HCl}$ concentration}

We evaluated the effects of hydrochloric acid concentration on the extraction yield $0.1 \mathrm{~mol} \mathrm{~L}^{-1}, 0.5 \mathrm{~mol} \mathrm{~L}^{-1}$, $1 \mathrm{~mol} \mathrm{~L}^{-1}$ and $3 \mathrm{~mol} \mathrm{~L}^{-1}$ (Table 4). According to Figure

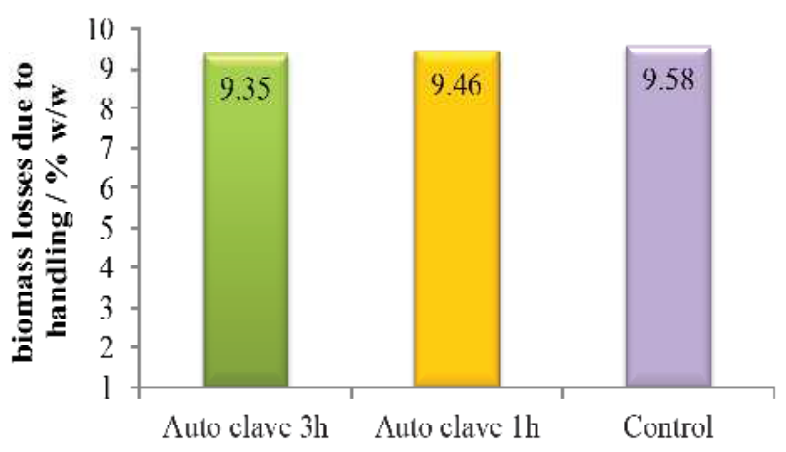

Figure 8. Losses of biomass heat treatment handling.

9 , it is shown that the extraction yield increases when acid concentration is also increased within the range set but at concentrations greater than $0.5 \mathrm{~mol} \mathrm{~L}^{-1}$, this effect is less pronounced with a tendency to stabilize. This tendency was similar to the one reported by Hernández, D et al. (2015) where small differences in sugar release were observed when the concentration of acid raised from $4 \%$ to $7 \% \mathrm{H}_{2} \mathrm{SO}_{4}$ for Nannochloropsis gaditana (11).

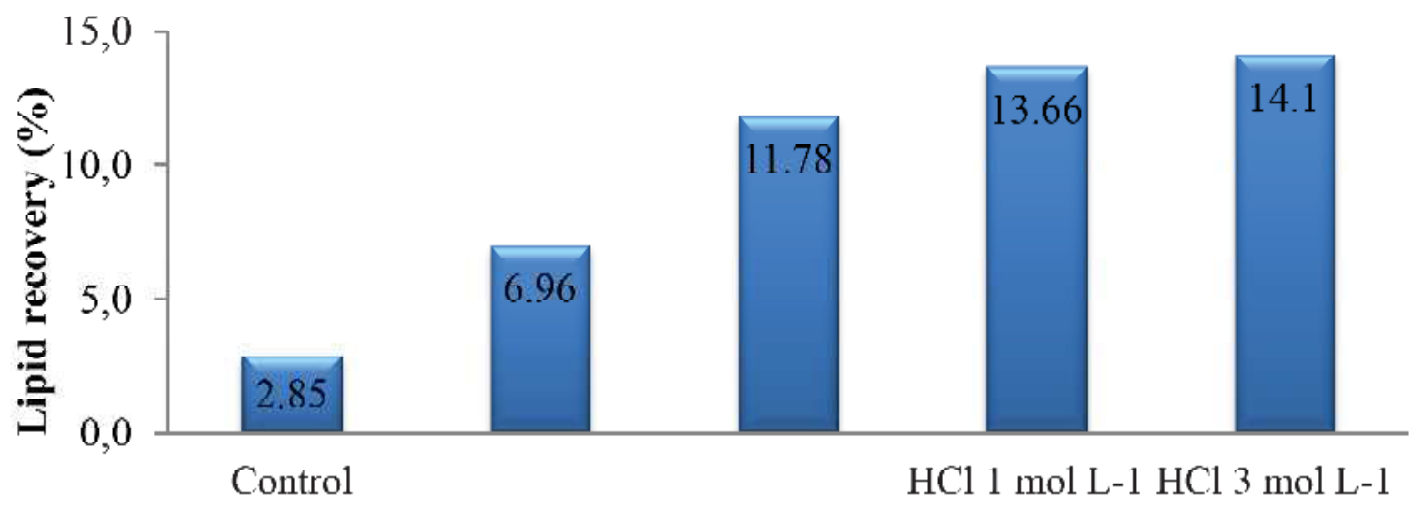

Figure 9. Effect of $\mathrm{HCl}$ concentration on the recovery rate of lipids.

Table 4. Data from the pretreatment with $\mathrm{HCl}$.

\begin{tabular}{lcccc}
\hline \multicolumn{1}{c}{ Pretreatment } & Average extracts / $\mathbf{g}$ & Standard deviation & $\mathbf{L R} / \% \mathbf{w} / \mathbf{w}$ & $\mathbf{B N} / \mathbf{\%} \mathbf{w} / \mathbf{w}$ \\
\hline $\begin{array}{l}\text { HCl 0.1 mol L-1 } \\
30 \text { min. agitation }\end{array}$ & 0.0233 & 0.0016 & 6.96 & 38.3 \\
HCl 0.5 mol L-1 & & & & \\
30 min. agitation & 0.0398 & 0.0033 & 11.78 & 55.2 \\
HCl 1 mol L-1 & 0.0463 & 0.0035 & 13.66 & 61.3 \\
$\begin{array}{l}30 \text { min. agitation } \\
\text { HCl 3 mol L-1 }\end{array}$ & 0.0478 & 0.0019 & 14.1 & 82.1 \\
30 min. agitation & & & & \\
\hline
\end{tabular}

LR: \% w/w lipid recovery in the total biomass; $\mathrm{BN}$ : \% w/w Biomass unrecovered. 
Cell disruption promoted with $\mathrm{HCl} 3 \mathrm{~mol} \mathrm{~L}^{-1}$ concentration, the highest percentage of recovery of lipids, is the $14.1 \% \mathrm{w} / \mathrm{w}$ of the total reported in Table 1 . But working at this concentration, involves the use of six times the amount of reagent for very little performance increase when compared with that obtained at 0.5 mol L-1 concentration of the acid, corresponding to $11.78 \% \mathrm{w} / \mathrm{w}$. In addition, higher concentrations of hydrochloric acid might increase the levels of corrosion that can occur in the teams involved throughout the process. Therefore, a solution of $0.5 \mathrm{~mol} \mathrm{~L}^{-1}$ hydrochloric acid was the most suitable for pretreatment of biomass, $250 \% \mathrm{w} / \mathrm{w}$ decline in spending on chemical agent worked to the maximum concentration, without affecting performance dramatically. In a similar way, Hernández, D et al. (2015) chose a 4\% $\mathrm{H}_{2} \mathrm{SO}_{4}$ solution for further experiments despite the highest sugar release was obtained with $7 \% \mathrm{H}_{2} \mathrm{SO}_{4}$, due to the slight differences observed in SR when applying a concentration of $4 \%, 7 \%$ and $10 \%$ of $\mathrm{H}_{2} \mathrm{SO}_{4}(11)$.

The changes caused by acid lysis of cells are not only significant as the percentage of recovery of lipids. A variable that reflects those changes is the percentage of unrecovered biomass (Figure 10). It is noted that when biomass is not treated (control), the losses are around $10 \% \mathrm{w} / \mathrm{w}$ by autoclave treatment, where biomass suffered no significant physical changes (Figure 8). These losses can be attributed to sample handling throughout the process. Considering this fact as truthful, the high percentages of unrecovered biomass with chemical treatments under a water-soluble components present in the cells, leaves the process (liquor) during the filtering stage before extraction of lipids.

\subsection{Organosolv Pretreatment}

Although organosolv pretreatment increased the recovery rate of lipids in more than $3 \% \mathrm{w} / \mathrm{w}$ over the 3 hour heat treatment, did not surpass the results obtained with $\mathrm{HCl} 0.5 \mathrm{~mol} \mathrm{~L}^{-1}$. The time of organosolv pretreatment on the enzymatic hydrolysis of cellulose was studied by other authors, who reported it as the only variable with individual effect significant due to the response variable concentration increased when the time of pretreatment was also increased (12). Nevertheless, this pretreatment involves high energy costs, a longer exposure time and use more chemicals. All this makes it inconvenient to use as a method of pretreatment prior to cell disruption with ethanolhexane extraction.

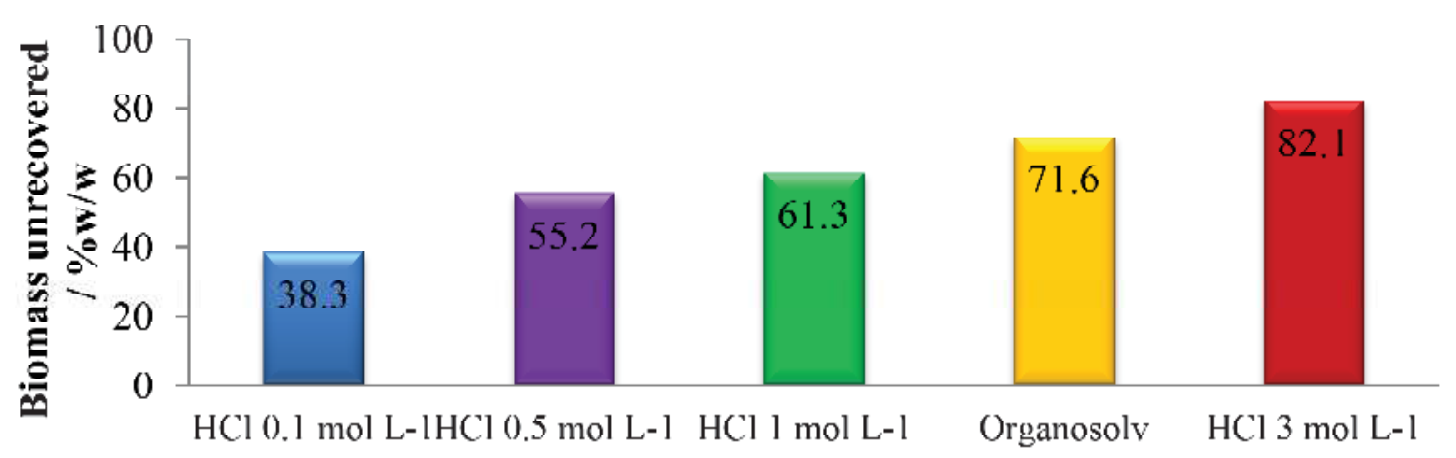

Figure 10. Not recovered biomass in pretreatment with $\mathrm{HCl}$ and Organosolv.

Table 5. Data from the pretreatment organosolv.

\begin{tabular}{|c|c|c|c|c|}
\hline Pretreatment & Average extracts /g & Standard deviation & LR / \% w/w & BN / \% w/w \\
\hline Organosolv & 0.215 & 0.0079 & 9.55 & 71.6 \\
\hline
\end{tabular}

LR: \% w/w lipid recovery in the total biomass; BN: \% w/w Biomass unrecovered.

\subsection{Comparison of pretreatments}

The values taken by the response variable $\left(\mathrm{L}_{\mathrm{R}}\right)$ shows clearly that the chemical treatment with $\mathrm{HCl} 0.5 \mathrm{~mol}$ $\mathrm{L}^{-1}$ was the most appropriate in comparison with thermal and organosolv pretreatment (Figure 11). This extraction method has lower yields compared tradi- tional procedures for the recovery of lipids, but the product obtained is mainly composed of neutral lipids due to the selectivity of hexane, being this the most suitable fraction for later processes of esterification, transesterification or hydro-treatment. 


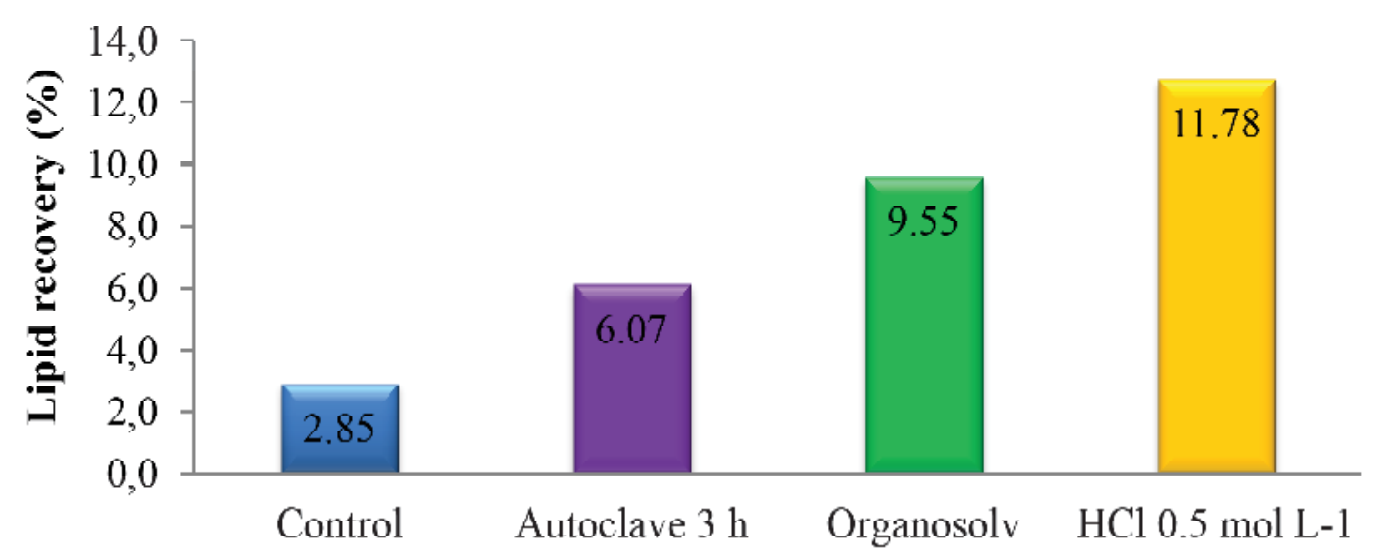

Figure 11. Comparison of biomass pretreatments.

\section{CONCLUSIONS}

A methodology for the oil extraction from microalgae using biomass of the genera Nannochloropsis sp. was developed. This process consists of two main stages: 1) chemical cell disruption with a solution of hydrochloric acid 2) Extraction of lipids with ethanol / hexane based on the methodology proposed, oil extraction with ethanol and purification with hexane.

The recovery rate of lipids was proportional to the concentration of hydrochloric acid within the range established for the pretreatment of biomass. However, an acid concentration of $0.5 \mathrm{~mol} \mathrm{~L}^{-1}$ was the most suitable for the cell disruption process, reducing by $250 \%$ $\mathrm{w} / \mathrm{w}$ reagent consumption compared to the maximum concentration worked, without significantly affecting the extraction yield.

Thermal pretreatment showed a significant increase in the percentage recovery of lipids for biomass without pre-treat but could not overcome any of the results obtained with the other pretreatments. An increase in operating time by three hours is an unnecessary energy expenditure.

The moisture content in the sample pretreated is not favorable for the extraction process due to decreases the concentration of ethanol, thereby reducing its extraction capacity. Therefore it is necessary to dry the biomass pre-treated before the lipid extraction process.

The use of more chemicals, together with low yields, makes the method organosolv pretreatment inconvenient for cell disruption, prior to lipid extraction with ethanol / hexane.

\section{ACKNOWLEDGMENTS}

The authors thanks to Universidad de Cartagena, the Colombian Agriculture \& Rural Development Ministry, the Colombian Department of Science, Technology and Innovation COLCIENCIAS, and the Colombian Petroleum Institute ICP-ECOPETROL for supporting this work.

\section{BIBLIOGRAPHY}

1. Hoekman SK. Biofuels in the U.S. - Challenges and Opportunities. Renew Energy. 2009 Jan;34(1):1422.

2. Nigam PS, Singh A. Production of liquid biofuels from renewable resources. Prog Energy Combust Sci. 2011 Feb;37(1):52-68.

3. Li Y, Horsman M, Wang B, Wu N, Lan CQ. Effects of nitrogen sources on cell growth and lipid accumulation of green alga Neochloris oleoabundans. Appl Microbiol Biotechnol. 2008 Dec;81(4):629-36.

4. Mata TM, Martins AA, Caetano NS. Microalgae for biodiesel production and other applications: A 
review. Renew Sustain Energy Rev. 2010 Jan;14(1):217-32.

5. Peñaranda LA, Sepúlveda KJ, Álvarez YE, González A, Kafarov V. Evaluation of lipid and monosaccharide obtaining routes of microalgae biomass under the biore-finery concept. ION. 2011;24(2):1322.

6. Fajardo AR, Cerdán LE, Medina AR, Fernández FGA, Moreno PAG, Grima EM. Lipid extraction from the microalgaPhaeodactylum tricornutum. Eur J Lipid Sci Technol. 2007 Feb;109(2):120-6.

7. Dos Santos RR, Moreira DM, Kunigami CN, Aranda DAG, Teixeira CMLL. Comparison between several methods of total lipid extraction from Chlorella vulgaris biomass. Ultrason Sonochem. 2015 Jan;22:95-9.

8. Miranda JR, Passarinho PC, Gouveia L. Pre-treatment optimization of Scenedesmus obliquus microalga for bioethanol production. Bioresour Techno. 2012 Jan;104:342-8.

9. Günerken E, D’Hondt E, Eppink MHM, Garcia-Gonzalez L, Elst K, Wijffels RH. Cell disruption for microalgae biorefineries. Biotechnol Adv. 2015 Feb;33(2):243-60.

10. Spiden EM, Scales PJ, Yap BHJ, Kentish SE, Hill DRA, Martin GJO. The effects of acidic and thermal pretreatment on the mechanical rupture of two industrially relevant microalgae: Chlorella sp. and Navicula sp. Algal Res. 2015 Jan; 7:5-10.

11. Hernández D, Riaño B, Coca M, García-González MC. Saccharification of carbohydrates in microalgal biomass by physical, chemical and enzymatic pre-treatments as a previous step for bioethanol production. Chem Eng J. 2015 Feb;262:939-45.

12. Mesa L, López N, Cara C, Castro E, González E, Mussatto SI. Techno-economic evaluation of strategies based on two steps organosolv pretreatment and enzymatic hydrolysis of sugarcane bagasse for ethanol production. Renew Energy. 2016 Feb;86:270-9. 